University of Wollongong

Research Online

Australian Institute for Innovative Materials -

Papers

Australian Institute for Innovative Materials

$1-1-2012$

\title{
LiFeP04-Fe2P-C composite cathode: An environmentally friendly promising electrode material for lithium-ion battery
}

M. Mahfuzur Rahman

University of Wollongong

Jiazhao Wang

University of Wollongong, jiazhao@uow.edu.au

Rong Zeng

University of Wollongong, rzeng@uow.edu.au

David Wexler

University of Wollongong, david_wexler@uow.edu.au

Hua-Kun Liu

University of Wollongong, hua@uow.edu.au

Follow this and additional works at: https://ro.uow.edu.au/aiimpapers

Part of the Engineering Commons, and the Physical Sciences and Mathematics Commons

Research Online is the open access institutional repository for the University of Wollongong. For further information contact the UOW Library: research-pubs@uow.edu.au 


\title{
LiFePO4-Fe2P-C composite cathode: An environmentally friendly promising electrode material for lithium-ion battery
}

\begin{abstract}
In this investigation, the synthesis strategy is involved the creation of LiFeP04-Fe2P-C composites with a porous conductive architecture, which includes distinct regions or clusters containing antiferromagnetic $\mathrm{LiFePO} 4$ in close proximity to ferromagnetic Fe2P. The microstructure is achieved by using a simple ultrafast solvent assisted manual grinding method, combined with solid state reaction, which can replace the time-consuming high energy ball milling method. The crystalline structure, morphology, and electrochemical characterization of the synthesised product are investigated systematically. The electrochemical performance is outstanding, especially the high $\mathrm{C}$ rate. The composite cathode is found to display specific capacity of $167 \mathrm{mAh}$ g- 1 at $0.2 \mathrm{c}$ and $146 \mathrm{mAh}$ g- 1 at $5 \mathrm{c}$ after 100 cycles, respectively. At the high current density of $1700 \mathrm{~mA} \mathrm{g-1}$, it exhibits long-term cycling stability, retaining around 96 per cent of its original discharge capacity beyond 1000 cycles, which can meet the requirements of a lithiumion battery for large-scale power applications. The obtained results have demonstrated that the fabrication of samples with strong and extensive antiferromagnetic and ferromagnetic interface coupling of LiFeP04/Fe2P provides a versatile strategy toward improving the electrochemical properties of LiFePO4 materials and also opens up a new window for material scientists to further study the new exchange bias phenomenon and its ability to enhance the electrochemical performance of lithium-ion battery electrode.
\end{abstract}

\section{Keywords}

material, lithium, ion, battery, c, composite, cathode, environmentally, friendly, promising, electrode, lifepo4, fe2p

\section{Disciplines}

Engineering | Physical Sciences and Mathematics

\section{Publication Details}

Rahman, M., Wang, J., Zeng, R., Wexler, D. \& Liu, H. K. (2012). LiFePO4-Fe2P-C composite cathode: An environmentally friendly promising electrode material for lithium-ion battery. Journal of Power Sources, 206 (May), 259-266. 


\title{
$\mathrm{LiFePO}_{4}-\mathrm{Fe}_{2} \mathrm{P}-\mathrm{C}$ Composite Cathode: An Environmentally Friendly High Performance Lithium-ion Battery Material for EVs/HEVs Application
}

\author{
Md. Mokhlesur Rahman", Jia-Zhao Wang, Rong Zeng, David Wexler, Hua-Kun Liu
}

In the new century, clean and renewable energy storage devices have become the foci of both the building industry and research development. ${ }^{[1]}$ Lithium ion batteries, as one of the most promising battery technologies, have attracted much attention due to their fast boom of market share with the most advanced electrochemical energy storage and conversion system for a wide range of green applications, including hybrid electric vehicles (HEVs), plug-in hybrid electric vehicles (PHEVs), and stationary energy storage for solar and wind electricity generation as well as smart grids. ${ }^{[1,2]}$ However, for EVs/HEVs applications, commercialized lithium-ion batteries do not yet meet the required combinations of high energy density, high power, and high rate capability. Apart from the search for new or improved electrode materials with higher energy densities, ${ }^{[3-5]}$ the enhancement of electrode capacity retention at high charge/discharge rates is one main challenges of lithium-ion battery research. Since the pioneering work by Padhi et al. ${ }^{[6]}$ olivine-like $\mathrm{LiFePO}_{4}$ appears to be an interesting positive electrode material for lithium-ion batteries, in particular for high power application, because of its high theoretical capacity $\left(170 \mathrm{mAh} \mathrm{g}^{-1}\right)$, acceptable operating voltage $\left(3.4 \mathrm{~V}\right.$ vs. $\left.\mathrm{Li}^{+} / \mathrm{Li}\right)$, low cost, environmental friendliness, long cycle life, cell safety, and high thermal stability. ${ }^{[2,6,7]}$ Nevertheless, a major limitation of this material, which prevents it from being used in large-scale applications, is its poor high-rate performance, owing to its low electronic conductivity and low ionic diffusion coefficient. ${ }^{[8,9]}$ However, the long term cycling stability at high current rate is still a great challenge for this material as it is a compulsory requirement for lithium ion batteries to have long cycle life for EVs/HEVs application. Recently, ultrafast charging and discharging at very high rate have been reported for the $\mathrm{LiFePO}_{4}$ material through creating an ion conducting lithium phosphate coating on the surface of $\mathrm{LiFePO}_{4}$ nanoparticles but their reported cycle number is not good enough. ${ }^{[10]} \mathrm{A}$ satisfactory long term cycling stability has been achieved through the formation of mesoporous $\mathrm{LiFePO}_{4} / \mathrm{C}$ nanocomposite (118 mAh g ${ }^{-1}$ at $10 \mathrm{C}$ after 1000 cycles) ${ }^{[2]}$ and by creating $\mathrm{LiFePO}_{4} /$ carbon composite $\left(\sim 85 \mathrm{mAh} \mathrm{g}^{-1}\right.$ at $10 \mathrm{C}$ after 2400 cycles) via high-energy ball milling combined with spray-drying method. ${ }^{[11]}$ Both of these reported results satisfy the long term cycling but their specific discharge capacity is not as high as we expect and thus, there is much more room for further improvement.

[*] M.M. Rahman, Dr. J.Z. Wang, Dr. R. Zeng, Prof. H.K. Liu Institute for Superconducting \& Electronic Materials and ARC Centre of Excellence and Electromaterials Science University of Wollongong

Wollongong, NSW 2522 (Australia)

Fax: (+) 61242215731

E-mail:mmr543@uowmail.edu.au

Dr. D. Wexler

Faculty of Engineering

University of Wollongong

Wollongong, NSW 2522 (Australia)

[**] The authors are grateful for funding from the Australian Research Council (ARC) under an ARC Centre of Excellence Program (CE0561616) and an ARC Discovery project (DP0987805). The authors also thank Dr. T. Silver for critical reading of the manuscript.

Supporting information for this article is available on the WwW under http://www.angewandte.org or from the author.
In this investigation, our synthesis strategy has been involved to create porous conductive architecture of $\mathrm{LiFePO}_{4}-\mathrm{C}$ composite with an antiferromagnetic (AFM) and ferromagnetic (FM) cluster interface coupling of $\mathrm{LiFePO}_{4} / \mathrm{Fe}_{2} \mathrm{P}$ through a solvent assisted modified solid state reaction method, which is quite different from the others reported in the literature. Herein, we report on "exchange bias (EB)" effect due to $\mathrm{LiFePO}_{4} / \mathrm{Fe}_{2} \mathrm{P}$ interface coupling and their enhancement in electrochemical performance of $\mathrm{LiFePO}_{4}-\mathrm{Fe}_{2} \mathrm{P}-\mathrm{C}$ composite cathode. The electrochemical measurements demonstrated that the synthesised $\mathrm{LiFePO}_{4}-\mathrm{Fe}_{2} \mathrm{P}-\mathrm{C}$ composite delivered a high capacity of $167 \mathrm{mAh} \mathrm{g}^{-1}$ at $0.2 \mathrm{C}$ at $100^{\text {th }}$ cycle and displayed long term cycling stability with a capacity retention of around $96 \%\left(131 \mathrm{mAh} \mathrm{g}^{-1}\right)$ even after 1000 cycles at 10C. To the best of our knowledge, this is the best high rate long-term cycling performance for $\mathrm{LiFePO}_{4} / \mathrm{C}$ composite cathode material reported so far.

The XRD patterns of the samples are shown in Figure S1 (Supporting Information). The profiles of the diffraction peaks could be indexed according to the olivine $\mathrm{LiFePO}_{4}$ phase (JCDPS Card Number $40-1499)$. The illegible $\mathrm{Fe}_{2} \mathrm{P}$ peak $\left(2 \theta=40.28^{\circ}\right)$ in XRD patterns for the carbon coated samples indicate that it begins to form the iron phosphide phase (barringerite $\mathrm{Fe}_{2} \mathrm{P}$ ) during the annealed process and it usually exist in the form of nanosized clusters. ${ }^{[12]} \mathrm{We}$ also have collected the XRD pattern of bare- $\mathrm{LiFePO}_{4}$ and have not found the illegible $\mathrm{Fe}_{2} \mathrm{P}$ peaks, it means that the residue coating carbon originated from the citrate framework has acted as the reductive under $\mathrm{Ar}$ atmosphere during the annealed process in our synthesis system. To estimate the amount of amorphous carbon in the $\mathrm{LiFePO}_{4}-\mathrm{Fe}_{2} \mathrm{P}-\mathrm{C}$ composites, TGA was carried out in air (Figure $\mathrm{S} 2$ in the Supporting Information). it was estimated that the amount of amorphous carbon in the composites were approximately 5.8 wt.\% C [ $\left.\mathrm{LiFePO}_{4}-\mathrm{Fe}_{2} \mathrm{P}-\mathrm{C}(1)\right], 10.4$ wt.\% C $\left[\mathrm{LiFePO}_{4}-\mathrm{Fe}_{2} \mathrm{P}-\mathrm{C}\right.$ (2)], and 19.9 wt.\% $\mathrm{C}\left[\mathrm{LiFePO}_{4}-\mathrm{Fe}_{2} \mathrm{P}-\mathrm{C}\right.$ (3)] obtained from different amount of citric acid. The specific surface areas of the synthesised products were also measured by the $15 \mathrm{BET}_{2}$ adsorption method. LiFePO $-\mathrm{Fe}_{2} \mathrm{P}-\mathrm{C}$ (1) composite shows the highest specific surface area $\left(33.14 \mathrm{~m}^{2} \mathrm{~g}^{-1}\right.$ ), while bare- $\mathrm{LiFePO}_{4}, \mathrm{LiFePO}_{4}-\mathrm{Fe}_{2} \mathrm{P}-\mathrm{C}$ (2), and $\mathrm{LiFePO}_{4}-\mathrm{Fe}_{2} \mathrm{P}-\mathrm{C}$ (3) have specific surface areas of $1.17 \mathrm{~m}^{2} \mathrm{~g}^{-1}$, $16.74 \mathrm{~m} \mathrm{~m}^{2} \mathrm{~g}^{-1}$, and $14.25 \mathrm{~m}^{2} \mathrm{~g}^{-1}$, respectively. Field emission scanning electron microscopy (FESEM) images of the bare$\mathrm{LiFePO}_{4}$ and $\mathrm{LiFePO}_{4}-\mathrm{Fe}_{2} \mathrm{P}-\mathrm{C}$ composites with different carbon content are shown in Figure 1. It is obviously observed that the growth of the $\mathrm{LiFePO}_{4}$ grains is inhibited by the formed carbon and $\mathrm{Fe}_{2} \mathrm{P}$ during the heat treatment process. According to previous researches, the particle size and electrochemical polarization can be reduced effectively only when $\mathrm{LiFePO}_{4}$ particle surface is coated by conductive carbon. ${ }^{[8,13]}$ In Figure 1 (b-d), the FESEM observation reveals an abrupt particle growth with increasing carbon content in the sample, which maybe caused by the agglomeration of the excessive carbon in the sample where $\mathrm{Fe}_{2} \mathrm{P}$ nanoclusters are being trapped. The porous network structure along with small particles and rough surfaces can be clearly observed in Figure 1 (b). As shown in Figure 1 (c, d), it is obvious that the porous network structure with rough surfaces disappear and agglomerated larger particles with smooth surfaces appear. FESEM high-contrast backscattered imaging (Figure 2) of sectioned powders was performed with qualitative calibration of the three most distinct phases $\left(\mathrm{Fe}_{2} \mathrm{P}\right.$, $\mathrm{LiFePO}_{4}$, and C) present in local regions of constant grey level. This was achieved using EDS spot analysis performed on regions of constant grey level (Figure S3 in the Supporting Information). 
Examination of Figure 2(b-d) reveals the presence of inhomogeneous distributions of nano $\mathrm{Fe}_{2} \mathrm{P}$ particles (white), in a highly porous architecture of $\mathrm{LiFePO}_{4}$ (light grey) and carbon (dark grey).
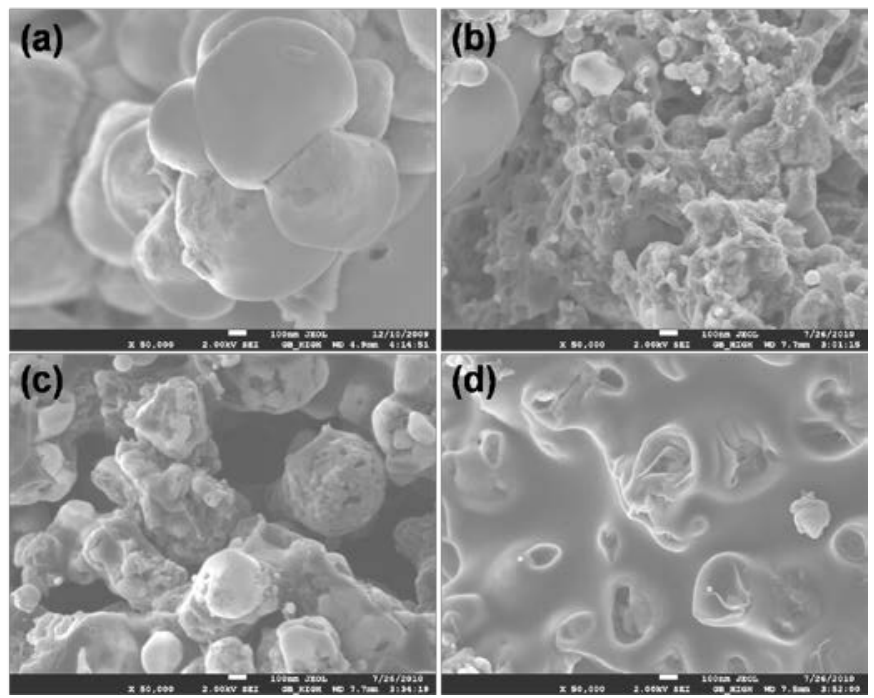

Figure 1. Secondary electron FESEM micrographs of (a) Bare$\mathrm{LiFePO}_{4}$, (b) $\mathrm{LiFePO}_{4}-\mathrm{Fe}_{2} \mathrm{P}-\mathrm{C}$ (1), (c) $\mathrm{LiFePO}_{4}-\mathrm{Fe}_{2} \mathrm{P}-\mathrm{C}$ (2), and (d) $\mathrm{LiFePO}_{4}-\mathrm{Fe}_{2} \mathrm{P}-\mathrm{C}$ (3).

Despite the inhomogeneous nature of microstructures, it was observed that the $\mathrm{LiFePO}_{4}-\mathrm{Fe}_{2} \mathrm{P}-\mathrm{C}$ composite containing 5.8 wt.\% C (Figure 2(b)) exhibited the largest fraction of local areas comprising fine distribution of $\mathrm{Fe}_{2} \mathrm{P}$ particles in close contact with $\mathrm{LiFePO}_{4}$ and carbon, (compare Figure 2(b) with Figure 2(c) and (d)). It was also observed that this sample had a particularly porous and highly porous conductive architecture (Figure S4 in the Supporting Information). These observations are consistent with the formation of a higher fraction of $\mathrm{LiFePO}_{4} / \mathrm{Fe}_{2} \mathrm{P}$ interface coupling with implications for magnetic properties and thus, magnetic hysteresis loop was measured. With the increasing carbon content, the $\mathrm{Fe}_{2} \mathrm{P}$ particles connect with the primary particles of $\mathrm{LiFePO}_{4}$ and become denser caused by the agglomeration of the excessive carbon in the sample where $\mathrm{Fe}_{2} \mathrm{P}$ particles are being trapped (Figure 2(d)).

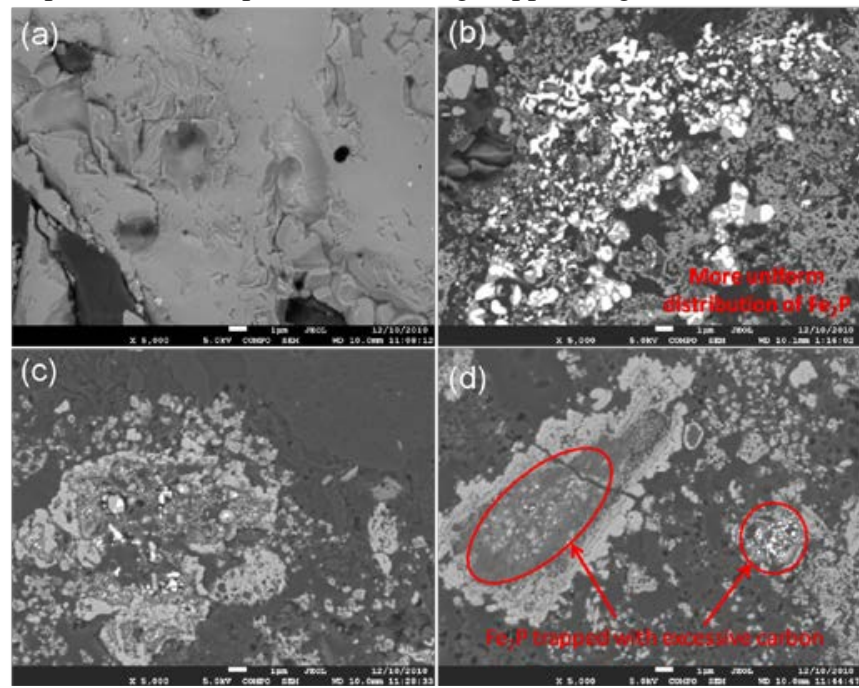

Figure 2. High contrast backscattered (BS) FESEM micrographs of (a) Bare- $\mathrm{LiFePO}_{4}$, (b) $\mathrm{LiFePO}_{4}-\mathrm{Fe}_{2} \mathrm{P}-\mathrm{C}$ (1), (c) $\mathrm{LiFePO}_{4}-\mathrm{Fe}_{2} \mathrm{P}-\mathrm{C}$ (2), and (d) $\mathrm{LiFePO}_{4}-\mathrm{Fe}_{2} \mathrm{P}-\mathrm{C}$ (3).

Preliminary magnetic measurement investigations (Figure 3) revealed additional information concerning structural evolution of the samples. However, so far there has been no experimental determination of exchange bias (EB) effect of $\mathrm{LiFePO}_{4} / \mathrm{Fe}_{2} \mathrm{P}$ interface coupling in $\mathrm{LiFePO}_{4}$ materials, even though the magnetic structure and properties of $\mathrm{LiFePO}_{4}$ have been re-examined theoretically and experimentally. ${ }^{[14,15]}$ The exchange interaction at the interface between a ferromagnetic (FM) and antiferromagnetic (AFM) component often results in an interesting phenomenon called "exchange bias" (EB), which is manifested by a shift in the hysteresis loop along the field axis when the system is cooled down in an external magnetic field. ${ }^{[16,17]}$ Comparing to other samples, the huge shift in the magnetic hysteresis loop is observed for the $\mathrm{LiFePO}-\mathrm{Fe}_{2} \mathrm{P}-\mathrm{C}$ (1) sample, in which the magnitude of the shift in the field axis is defined as the EB (exchange bias) field, $-H_{\mathrm{E}}=\left(H_{1}\right.$ $\left.+H_{2}\right) / 2$, where $H_{1}$ and $H_{2}$ are the left and right coercive fields, respectively, ${ }^{[16]}$ is shown in Figure 3 (a-d). The maximum value of $H_{\mathrm{E}}$ is $634 \mathrm{Oe}$ at 500 Oe cooling field for the $\mathrm{LiFePO}_{4}-\mathrm{Fe}_{2} \mathrm{P}-\mathrm{C}$ (1) sample, which is larger than the value for other samples at $5 \mathrm{~K}$. The comparison of the EB effect among the samples indicates that the EB effect is stronger for the $\mathrm{LiFePO}_{4}-\mathrm{Fe}_{2} \mathrm{P}-\mathrm{C}$ (1) sample and is in ascending order of $\mathrm{LiFePO}_{4}-\mathrm{Fe}_{2} \mathrm{P}-\mathrm{C}$ (1) $>\mathrm{LiFePO}_{4}-\mathrm{Fe}_{2} \mathrm{P}-\mathrm{C}$ (2)> $\mathrm{LiFePO}_{4}-\mathrm{Fe}_{2} \mathrm{P}-\mathrm{C}(3)>$ Bare-LiFePO . The reason could be attributed to the largest fraction of local areas comprising fine distribution of $\mathrm{Fe}_{2} \mathrm{P}$ particles in close contact with $\mathrm{LiFePO}_{4}$ which leads to the formation of more and strong interface coupling of $\mathrm{LiFePO}_{4}$ (AFM) $/ \mathrm{Fe}_{2} \mathrm{P}(\mathrm{FM})$ in $\mathrm{LiFePO}_{4}-\mathrm{Fe}_{2} \mathrm{P}-\mathrm{C}$ (1) sample compared with other samples. The results are also well supported by the BET surface areas were found of $33.14,16.74,14.25$, and $1.17 \mathrm{~m}^{2} \mathrm{~g}^{-1}$ for the $\mathrm{LiFePO}_{4}-\mathrm{Fe}_{2} \mathrm{P}-\mathrm{C}$ (1), $\mathrm{LiFePO}_{4}-\mathrm{Fe}_{2} \mathrm{P}-\mathrm{C}$ (2), $\mathrm{LiFePO}_{4}-\mathrm{Fe}_{2} \mathrm{P}-\mathrm{C}$ (3), and bare- $\mathrm{LiFePO}_{4}$, respectively, and by electrochemical impedance spectroscopy (EIS) analysis (described later).
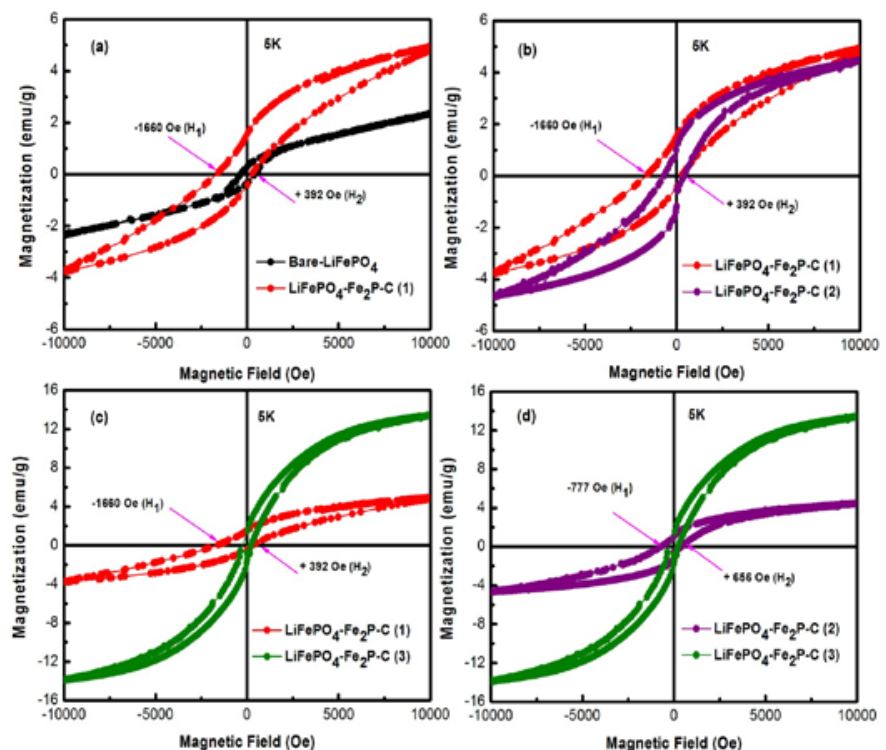

Figure 3. The magnetic hysteresis loop measured at $5 \mathrm{~K}$ between \pm 10000 Oe after field cooling with 500 Oe.

Transmission electron microscopy (TEM) was used to investigate the morphology and structure of the $5.8 \mathrm{wt} . \% \mathrm{C}\left(\mathrm{LiFePO}_{4}-\mathrm{Fe}_{2} \mathrm{P}-\mathrm{C}\right.$ (1)) composite, as shown in Figure S5 (Supporting Information). It is noticed that the crystallite size of this composite is much smaller than that of the bare $\mathrm{LiFePO}_{4}$. On the otherhand, $\mathrm{LiFePO}_{4} / \mathrm{Fe}_{2} \mathrm{P}$ interface couplings are clearly observed among the carbon coated samples (Figure S6 in the Supporting Information).

The electrochemical performances of the prepared samples were evaluated systematically using CR 2032 coin cells. The short term cycle life performances for the bare- $\mathrm{LiFePO}_{4}$ and $\mathrm{LiFePO}_{4^{-}}$ $\mathrm{Fe}_{2} \mathrm{P}-\mathrm{C}$ composite electrodes at $10 \mathrm{C}$ charge/discharge rates are shown in Figure 4 (a).The initial discharge capacities were measured to be $43,59,89$, and $137 \mathrm{mAh} \mathrm{g}^{-1}$ with a capacity retention of 40,56 , 84 , and $136 \mathrm{mAh} \mathrm{g}^{-1}$ at the $120^{\text {th }}$ cycle at $10 \mathrm{C}$ rate for the bare$\mathrm{LiFePO}_{4}, \mathrm{LiFePO}_{4}-\mathrm{Fe}_{2} \mathrm{P}-\mathrm{C}$ (3), $\mathrm{LiFePO}_{4}-\mathrm{Fe}_{2} \mathrm{P}-\mathrm{C}$ (2), and $\mathrm{LiFePO}_{4^{-}}$ $\mathrm{Fe}_{2} \mathrm{P}-\mathrm{C}$ (1) electrodes, respectively. The electrochemical performance among the carbon coated samples is in ascending order of $\mathrm{LiFePO}_{4}-\mathrm{Fe}_{2} \mathrm{P}-\mathrm{C}(1)>\mathrm{LiFePO}_{4}-\mathrm{Fe}_{2} \mathrm{P}-\mathrm{C}(2)>\mathrm{LiFePO}_{4}-\mathrm{Fe}_{2} \mathrm{P}-\mathrm{C}$ (3). Electrode, composed of $\mathrm{LiFePO}_{4}-\mathrm{Fe}_{2} \mathrm{P}-\mathrm{C}$ (1) (5.8 wt.\%C) shows the best electrochemical performances even at high current density 
of $10 \mathrm{C}$. In order to fully estimate the electrochemical performance of the $\mathrm{LiFePO}_{4}-\mathrm{Fe}_{2} \mathrm{P}-\mathrm{C}$ (1) (5.8 wt.\%C) composite electrode, the cycling behaviours at different current densities of $0.2,2,5$ and $10 \mathrm{C}$ were measured at the $100^{\text {th }}$ cycle and their corresponding chargedischarge voltage profile is shown in Figure 4 (c). The $\mathrm{LiFePO}_{4^{-}}$ $\mathrm{Fe}_{2} \mathrm{P}-\mathrm{C}$ (1) (5.8wt.\%C) composite electrode shows long and flat voltage plateaus in the 3.4-3.5 $\mathrm{V}$ range and the small voltage difference between the charge-discharge plateaus is representing of its good kinetics. This observation is also supported by the cyclic voltammogram (CV curve) shown in Figure 4 (d). The well defined sharp redox peaks in the range of 3.26 $-3.70 \mathrm{~V}$ should be attributed to the $\mathrm{Fe}^{2+} / \mathrm{Fe}^{3+}$ redox couple reaction, corresponding to lithium extraction and insertion in $\mathrm{LiFePO}_{4}$ crystal structure. ${ }^{[2]}$ The $100^{\text {th }}$ cycle discharge capacities were measured to be $167 \mathrm{mAh} \mathrm{g}^{-1}$ at 0.2 $\mathrm{C}, 159 \mathrm{mAh} \mathrm{g}^{-1}$ at $2 \mathrm{C}, 146 \mathrm{mAh} \mathrm{g}^{-1}$ at $5 \mathrm{C}$, and $136 \mathrm{mAh} \mathrm{g}^{-1}$ at $10 \mathrm{C}$ for the $\mathrm{LiFePO}_{4}-\mathrm{Fe}_{2} \mathrm{P}-\mathrm{C}$ (1) (5.8 wt.\%C) electrode, respectively. At the low current density of $0.2 \mathrm{C}$ ( 5 hours charge and 5 hours discharge), the obtained discharge capacity $\left(167 \mathrm{mAh} \mathrm{g}^{-1}\right)$ is very close to the theoretical capacity of $\mathrm{LiFePO}_{4}\left(170 \mathrm{mAh} \mathrm{g}^{-1}\right)$. Even at the high current rate of $10 \mathrm{C} \mathrm{(6} \mathrm{minutes} \mathrm{for} \mathrm{charging} \mathrm{and} 6$ minutes for discharging), a capacity of $136 \mathrm{mAh} \mathrm{g}^{-1}$ is still obtained, demonstrating that the $\mathrm{LiFePO}_{4}-\mathrm{Fe}_{2} \mathrm{P}-\mathrm{C}$ (1) (5.8 wt.\%C) composite can tolerate high rate charge and discharge. The capacity fading is observed only $\sim 18 \%$ with the increasing of charge-discharge rate from 0.2 to $10 \mathrm{C}$.
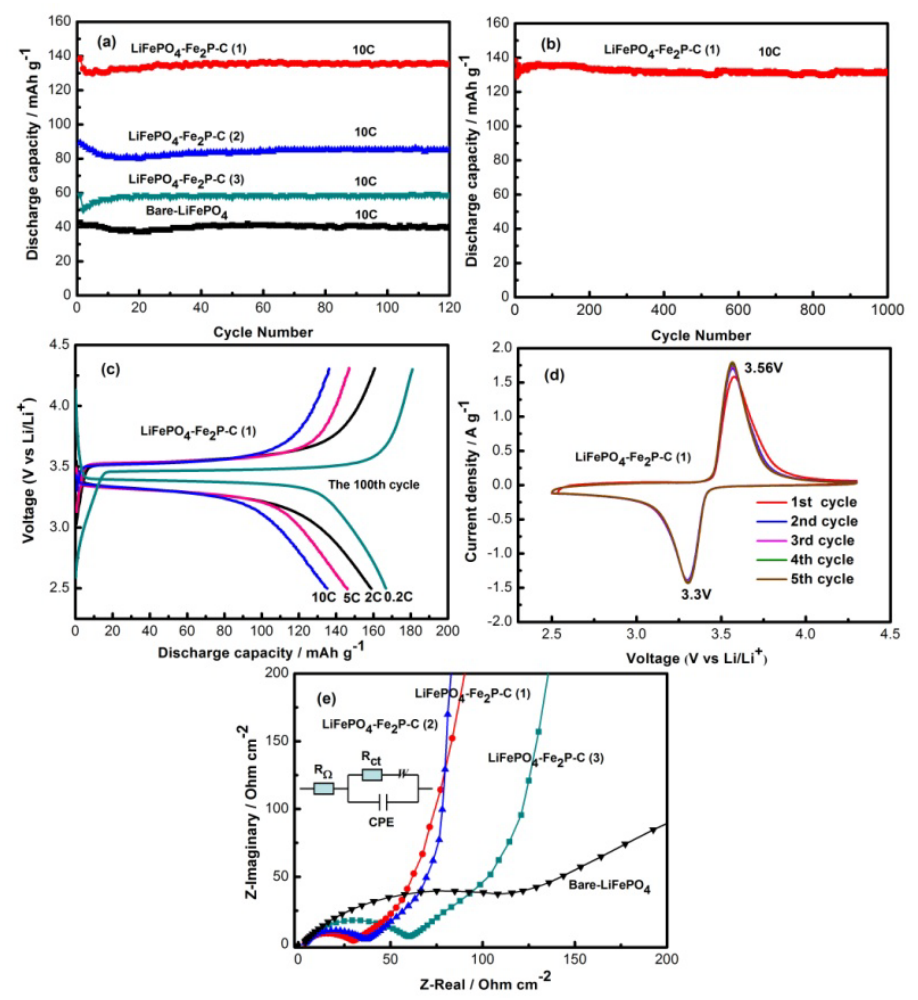

Figure 4. Short term cycle life performance (a), long term cycle life performance beyond 1000 cycles at $10 \mathrm{C}$ for the $\mathrm{LiFePO}_{4}-\mathrm{Fe}_{2} \mathrm{P}-\mathrm{C}$ (1) electrode (b), the $100^{\text {th }}$ cycle galvanostatic charge-discharge profiles at the different current densities from 0.2 to $10 \mathrm{C}$ between 4.3 and $2.5 \mathrm{~V}$ for $\mathrm{LiFePO}_{4}-\mathrm{Fe}_{2} \mathrm{P}-\mathrm{C}$ (1) electrode (c), cyclic voltammogram of $\mathrm{LiFePO}_{4}-\mathrm{Fe}_{2} \mathrm{P}-\mathrm{C}(1)$ electrode at a scan rate of 0.1 $\mathrm{mV} / \mathrm{s}$ (d), EIS spectra of the bare- $\mathrm{LiFePO}_{4}$ and $\mathrm{LiFePO}_{4}-\mathrm{Fe}_{2} \mathrm{P}-\mathrm{C}$ electrodes and the equivalent circuit (inset) used to fit the impedance data (e).

Furthermore, our composite electrode was life tested at a high current density of $1700 \mathrm{~mA} \mathrm{~g}^{-1}$ (10 C rate) for a long term cycling as batteries are required to operate at high current density and to have a cycle life of more than 2000 cycles for EVs/HEVs applications. ${ }^{[18]}$ Therefore, we cycled $\mathrm{LiFePO}_{4}-\mathrm{Fe}_{2} \mathrm{P}-\mathrm{C}$ (1) (5.8wt.\%C) electrode at $10 \mathrm{C}$ rate (6 minutes for charging and 6 minutes for discharging) for 1000 cycles (Figure 4 (b)). Surprisingly, the $\mathrm{LiFePO}_{4}-\mathrm{Fe}_{2} \mathrm{P}-\mathrm{C}$ (1)
(5.8 wt.\%C) electrode exhibited superior electrochemical performance with a capacity retention of around 96\% (131 mAh g $\left.{ }^{-1}\right)$ of its original discharge capacity after 1000 cycles at high current rate of $10 \mathrm{C}$. Such outstanding electrochemical performance certainly can meet the demands of many high power applications. However, to understand the effect of $\mathrm{LiFePO}_{4} / \mathrm{Fe}_{2} \mathrm{P}$ interface coupling along with carbon coating on the charge transfer resistance of electrodes, ac impedance measurements were carried out at room temperature (Figure 4 (e)). The impedance curves show one compressed semicircle in the medium-frequency region, which could be assigned to the charge-transfer resistance $\left(R_{\mathrm{ct}}\right)$. The spike at the low frequency end indicates the Warburg impedance $(W)$ of long-range lithium-ion diffusion. ${ }^{[19-21]}$ The charge transfer resistance $\left(R_{\mathrm{ct}}\right)$ was calculated to be $148 \Omega \mathrm{cm}^{-2}$ for the bare- $\mathrm{LiFePO}_{4}, 28 \Omega$ $\mathrm{cm}^{-2}$ for the $\mathrm{LiFePO}_{4}-\mathrm{Fe}_{2} \mathrm{P}-\mathrm{C}(1), 37 \Omega \mathrm{cm}^{-2}$ for the $\mathrm{LiFePO}_{4}-\mathrm{Fe}_{2} \mathrm{P}-\mathrm{C}$ (2), and $60 \Omega \mathrm{cm}^{-2}$ for the $\mathrm{LiFePO}_{4}-\mathrm{Fe}_{2} \mathrm{P}-\mathrm{C}$ (3) electrodes, respectively. According to the previous research, ${ }^{[22]}$ higher carbon content sample shows lower charge transfer resistance $\left(R_{\mathrm{ct}}\right)$ and generally this trend is also logical. Under this consideration, the $R_{\mathrm{ct}}$ should be in order of $\mathrm{LiFePO}_{4}-\mathrm{Fe}_{2} \mathrm{P}-\mathrm{C}$ (3) (19.9 wt.\% C) $<\mathrm{LiFePO}_{4^{-}}$ $\mathrm{Fe}_{2} \mathrm{P}-\mathrm{C}$ (2) (10.4 wt.\% C) < $\mathrm{LiFePO}_{4}-\mathrm{Fe}_{2} \mathrm{P}-\mathrm{C}$ (1) (5.8 wt.\% C), but the reality is inverse $\mathrm{LiFePO}_{4}-\mathrm{Fe}_{2} \mathrm{P}-\mathrm{C}(1)<\mathrm{LiFePO}_{4}-\mathrm{Fe}_{2} \mathrm{P}-\mathrm{C}(2)<$ $\mathrm{LiFePO}_{4}-\mathrm{Fe}_{2} \mathrm{P}-\mathrm{C}$ (3). At this point, we strongly believe that this $R_{\mathrm{ct}}$ is not only influenced by the carbon content but also strongly influenced by the interface coupling of $\mathrm{LiFePO}_{4} / \mathrm{Fe}_{2} \mathrm{P}$ clusters. Obviously, $\mathrm{LiFePO}_{4}-\mathrm{Fe}_{2} \mathrm{P}-\mathrm{C}$ (1) sample exhibits more and strong interface coupling of antiferromagnetic (AFM) and ferromagnetic (FM) clusters than that of other samples which increase the effective interface areas, facilitate charge transfer more faster, and reduce the charge transfer resistance, leading to the huge shift in the magnetic hysteresis loop ${ }^{[23,24]}$ So, the excellent electrochemical performances of the $\mathrm{LiFePO}_{4}-\mathrm{Fe}_{2} \mathrm{P}-\mathrm{C}$ (1) (5.8 wt.\%C) composite could be attributed to the porous conductive architecture with huge and strong interface coupling of $\mathrm{LiFePO}_{4} / \mathrm{Fe}_{2} \mathrm{P}$ that increase the contact area among the carbon, $\mathrm{Fe}_{2} \mathrm{P}$ clusters, and $\mathrm{LiFePO}_{4}$ particles, providing multi-dimension channels for charge transfer and reduce the resistances for lithium ion migration. Moreover, the composite with porous architecture can suck up electrolyte to shorten enormously the diffusive distance of lithium ion.

In conclusion, our results demonstrated that the fabrication of composite microstructure provides versatile strategies toward improving the electrochemical properties of $\mathrm{LiFePO}_{4}$ materials at higher $\mathrm{C}$ rate which can meet the requirements of a lithium-ion battery for large-scale power applications.

\section{Experimental Section}

A simple ultrafast solvent assisted manual grinding method, combined with solid state reaction has been developed to synthesize $\mathrm{LiFePO}_{4}-\mathrm{Fe}_{2} \mathrm{P}-\mathrm{C}$ composite with a porous conductive architecture. The grinding method involve here replaces time consuming high energy ball milling method. $\mathrm{LiCO}_{3}, \mathrm{FeC}_{2} \mathrm{O}_{4} .2 \mathrm{H}_{2} \mathrm{O}$, and $\mathrm{NH}_{4} \mathrm{H}_{2} \mathrm{PO}_{4}$ in a stoichiometric molar ratio of 1:1:1 were used as starting materials and citric acid $\left(\mathrm{C}_{6} \mathrm{H}_{8} \mathrm{O}_{7}\right)$ used as a reducing agent and carbon source as well. The reactants for preparing the precursor were ground thoroughly, and a slurry was made by mortar and pestle in acetone solvent to ensure intimate and homogeneous mixing at the atomic level. The slurry was then dried in oven at $60{ }^{\circ} \mathrm{C}$ to remove acetone from the slurry. To decompose the carbonate, oxalate, and phosphate, the dried mixture was placed in a tube furnace and heat-treated at $350^{\circ} \mathrm{C}$ for $10 \mathrm{~h}$ in argon flow. The resultant powders were cooled to room temperature and thoroughly reground. The powders were again calcined at $600{ }^{\circ} \mathrm{C}$ for $10 \mathrm{~h}$ under argon flow. Thus the bare- $\mathrm{LiFePO}_{4}$ and $\mathrm{LiFePO}_{4}-\mathrm{Fe}_{2} \mathrm{P}-\mathrm{C}$ composite containing 5.8 wt.\% C [ $\left[\mathrm{LiFePO}_{4}-\mathrm{Fe}_{2} \mathrm{P}-\mathrm{C}\right.$ (1)], 10.4 wt.\% C $\left[\mathrm{LiFePO}_{4}-\mathrm{Fe}_{2} \mathrm{P}-\mathrm{C}\right.$ (2)], and 19.9 wt.\% $\mathrm{C}\left[\mathrm{LiFePO}_{4}-\mathrm{Fe}_{2} \mathrm{P}-\mathrm{C}\right.$ (3)] were obtained using different amount of citric acid.

X-ray diffraction (XRD) data were collected on a GBC MMA generator. BET surface area of the synthesized materials was measured by a NOVA 1000 high speed gas sorption analyzer (Quantachrome Corporation, USA). Magnetic measurements were performed using a physical properties measurement system (PPMS) 14T magnetometer. The amounts of amorphous carbon in the composite samples were estimated using a 
TGA/DSC) 1 Star $^{\mathrm{e}}$ System. The morphologies and microchemistries of the samples were investigated by field emission SEM-EDS system (JEOL JSM7500FA with Brukker eds analysis system) and transmission electron microscopy (JEOL 2011, $200 \mathrm{kV}$ ). Samples for secondary electron imaging were prepared by dispersion onto carbon tape while samples for high contrast backscattered imaging analysis were prepared by mounting in conducting phenolic followed by metallographic grinding and polishing for examination in section. TEM samples were prepared by deposition of ground particles onto holey carbon support films. To test the electrochemical performance, powder samples were mixed with acetylene black (AB) (Cabot Australasia Pty Ltd.) and a binder, polyvinylidene fluoride (PVdF, SigmaAldrich), in a weight ratio of 80:15:5 in a solvent, $N$-methyl-2-pyrrolidone (NMP, Sigma-Aldrich, anhydrous, $99.5 \%$ ). The slurry was uniformly spread onto aluminium foil substrates with an area of $1 \mathrm{~cm}^{2}$. The coated electrodes were dried in a vacuum oven at $100{ }^{\circ} \mathrm{C}$ for $24 \mathrm{~h}$ and then pressed under a pressure. CR 2032 coin-type cells were assembled in an Ar-filled glove box (Mbraun, Unilab, Germany). The electrochemical coin cells contained a coated materials on aluminium foil as the working electrode, lithium foil as counter electrode and reference electrode, porous polypropylene as the separator, and 1 M LiPF6 in a 50:50 (v/v) mixture of ethylene carbonate and dimethyl carbonate (MERCK KgaA, Germany) as the electrolyte. The cells were galvanostatically charged and discharged in the range of 4.3-2.5 V at different rates of $0.2-10 \mathrm{C}$ using a computer-controlled charger system manufactured by Neware Battery Testers. Cyclic voltammetry (with a scan rate of $0.1 \mathrm{mVs}^{-1}$ between 4.3 and $2.5 \mathrm{~V}$ (versus $\mathrm{Li}^{-} \mathrm{Li}^{+}$)) and electrochemical impedance spectroscopy (EIS) were performed on the electrodes using a $\mathrm{CH}$ $660 \mathrm{C}$ electrochemistry workstation. The AC amplitude was $5 \mathrm{mV}$, and the frequency range applied was $100 \mathrm{kHz}-0.01 \mathrm{~Hz}$.

Received: ((will be filled in by the editorial staff))

Published online on ((will be filled in by the editorial staff))

Keywords: manual grinding $\cdot \mathrm{LiFePO}_{4}-\mathrm{Fe}_{2} \mathrm{P}-\mathrm{C}$ composite $\cdot \mathrm{Fe}_{2} \mathrm{P}$

phase $\cdot \mathrm{LiFePO}_{4} / \mathrm{Fe}_{2} \mathrm{P}$ interface coupling $\cdot$ Li-ion batteries

[1] D. Liu, G. Cao, Energy Environ. Sci. 2010, 3, 1218.

[2] G. Wang, H. Liu, J. Liu, S. Qiao, G. M. Lu , P. Munro, H. Ahn, Adv. Mater. 2010, 22, 4944.

[3] T. Zhang, L.J. Fu, H. Takeuchi, J. Suzuki, K. Sekine, T. Takamura, Y.P. Wu, J. Power Sources 2006, 159, 349.

[4] T. Zhang, L.J. Fu, J. Gao, L.C. Yang, Y.P. Wu, H.Q. Wu, Pure Appl. Chem. 2006, 781889.

[5] M.J. Noh, Y. Kwon, H. Lee, J. Cho, Y. Kim, M. Kim, Chem. Mater. 2005, 17, 1926.

[6] A. K. Padhi, K. S. Nanjundaswamy, J. B. Goodenough, J. Electrochem. Soc. 1997, 144, 1188.

[7] A. Yamada, S.C. Chung, K. Hinokuma, J. Electrochem. Soc. 2001, 148, A224.

[8] H. Huang, S.C. Yin, L.F. Nazar, Electrochem. Solid State Lett. 2001, 4, A170.

[9] Z.H. Chen, J.R. Dahn, J. Electrochem. Soc. 2002, 149, A1184

[10] B. Kang, G. Ceder, Nature 2009, 458, 190.

[11] S.J. Kwon, C.W. Kim, W.T. Jeong, K.S. Lee, J. Power Sources 2004, 137, 93.

[12] A. A. Salah, A. Mauger, C. M. Julien, F. Gendron, Materials Science \& Engineering B 2006, 129, 232.

[13] Y. Wang, Y. Wang, E. Hosono, K. Wang, H. Zhou, Angew. Chem. Int Ed. 2008, 477461.

[14] V. A. Streltsov, E. L. Belokoneva, V. G. Tsirelson, N. K. Hansen, Acta Crystallogr. B 1993, 49, 147.

[15] G. Rousse, J. R. Carvajal, S. Patoux, C. Masquelier, Chem. Mater 2003, 15, 4082

[16] W. H. Meiklejohn, C. P. Bean, Phys. Rev. 1956, 102, 1413.

[17] J. Nogués, J. Sort, V. Langlais, V. Skumryev, S. Suriñach, J. S. Muñoz, M. D. Baró, Phys. Rep. 2005, 422, 65.

[18] J. Liu, J. Wang, X. Yan, X. Zhang, G. Yang, A. F. Jalbout, R. Wang, Electrochim. Acta 2009, 54, 5656.

[19] F. Gao, Z. Tang, Electrochim. Acta 2008, 53, 5071.

[20] H.C. Shin, W.I. Cho, H. Jang, J. Power Sources 2006, 159, 1383.

[21] H.H. Chang, C.C. Chang, C.Y. Su, H.C. Wu, M.H. Yang, N.L. Wu, J. Power Sources 2008, 185, 466.

[22] X. Zhi, G. Liang, L. Wang, X. Ou, L. Gao, X. Jie, J. Alloys and Compounds 2010, 503, 370.

[23] K. De, M. Patra, S. Majumdar, S. Giri, J. Phys. D: Appl. Phys. 2008 $41,175007$.
[24] L. Liu, S. L. Yuan, Z. M. Tian, X. Liu, J. H. He, P. Li, C. H. Wang, X. F. Zheng, S. Y. Yin, J. Phys. D: Appl. Phys. 2009, 42, 045003. 
Entry for the Table of Contents (Please choose one layout)

Layout 1:

\section{Hybrid Composites}

Md. Mokhlesur Rahman*, Jia-Zhao Wang, Rong Zeng, David Wexler, HuaKun Liu

$$
\text { Page - Page }
$$

LiFePO $-\mathrm{Fe}_{2} \mathrm{P}-\mathrm{C}$ Composite Cathode: An Environmentally Friendly High Performance Lithium-ion Battery Material for EVs/HEVs Application ${ }^{* *}$
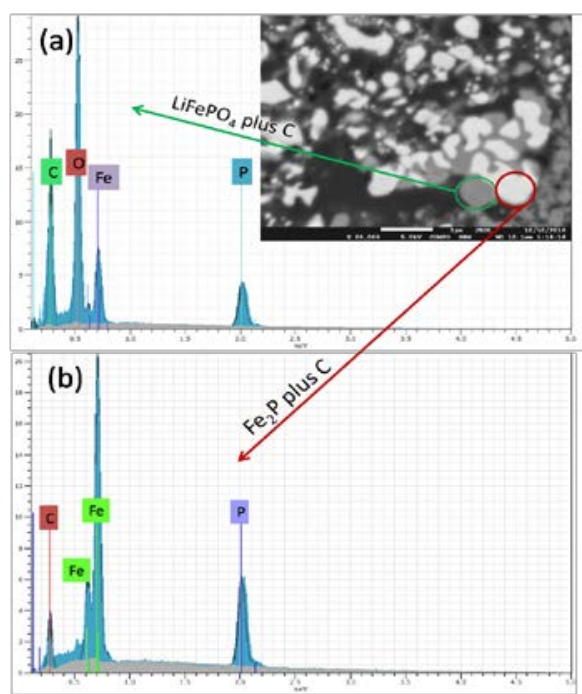

A simple ultrafast solvent assisted manual grinding method, combined with solid state reaction has been developed to synthesize $\mathrm{LiFePO}_{4}-\mathrm{Fe}_{2} \mathrm{P}-\mathrm{C}$ composite with a porous conductive architecture. The excellent electrochemical performances could be attributed to the porous conductive architecture with huge and strong interface coupling of $\mathrm{LiFePO}_{4} / \mathrm{Fe}_{2} \mathrm{P}$ that increase the contact area among the carbon, $\mathrm{Fe}_{2} \mathrm{P}$ clusters, and $\mathrm{LiFePO}_{4}$ particles, providing multi-dimension channels for charge transfer and reduce the resistances for lithium ion migration. 